Jurnal Agro 8(1), 2021

\title{
THE POTENCY OF MEXICAN SUNFLOWER EXTRACT AS THE REPLACEMENT OF MANURE AND RICE HUSK CHARCOAL IN BANANA SEEDLING
}

\section{POTENSI EKSTRAK BUNGA MATAHARI MEKSIKO SEBAGAI PENGGANTI PUPUK KANDANG DAN ARANG SEKAM PADI PADA BIBIT PISANG}

\author{
Andre Sparta*1, Arifah Rahmi ${ }^{2}$, Panca Jarot Santoso ${ }^{1}$, and Ida Fitrianingsih ${ }^{1}$ \\ ${ }^{1}$ Indonesian Tropical Fruit Research Institute, \\ JI. Raya Solok Aripan Km 8 Solok, Sumatera Barat, Indonesia 27356 \\ ${ }^{2}$ Dinas Tanaman Pangan, Hortikultura, dan Perkebunan \\ Kabupaten Lima Puluh Kota, Sarilamak, Kec. Harau, Kabupaten Lima Puluh Kota, Sumatera \\ Barat 26271
}

Korespondensi : ansparra@gmail.com

Diterima : 21 Januari 2021 / Disetujui : 06 Juli 2021

\begin{abstract}
In the nursery, media composition plays an essential role in the growth and development of plant seedlings. Extract of Mexican sunflower (Tithonia diversifolia) could be suitable for replacing organic manure and rice husk charcoal during the seedling phase. The purpose of this study is to examine the ability of Mexican sunflower extract to replace organic manure and rice husk charcoal as the source of nutrients for banana seedling. The study was arranged in a Completely Randomized Design with seven treatments and three replications. Extract of Mexican sunflower promotes plant growth (plant height, number of leaves, and leaf area), improves plant biomass, and improves soil chemical properties $\left(\mathrm{pH}\left(\mathrm{H}_{2} \mathrm{O}\right), \mathrm{C}\right.$ organic, and total $\mathrm{N})$. Application twice a week of Mexican sunflower into soil medium resulted superior in plant height, the number of leaves, leaf area, and total biomass of banana seedlings compared to other treatments. Extract of Mexican sunflower could replace organic manure and rice husk charcoal as the nutrient source in banana seedlings.
\end{abstract}

Keywords : planting media, Mexican sunflower, growth, banana

\section{ABSTRAK}

Pada saat pembibitan, komposisi media memiliki peranan penting terhadap pertumbuhan dan perkembangan bibit tanaman. Ekstrak bunga matahari Meksiko (Tithonia diversifolia) dapat menjadi pilihan yang cocok untuk menggantikan peran dari pupuk kandang dan sekam bakar pada fase pembibitan. Tujuan dari penelitian ini adalah untuk mempelajari kemampuan dari ekstrak bunga matahari Meksiko untuk menggantikan peran pupuk kandang dan sekam bakar sebagai sumber nutrisi bagi bibit pisang. Penelitian ini dilaksanakan dengan menggunakan Rancangan Acak Lengkap dengan tujuh perlakuan dan tiga ulangan. Ekstrak bunga matahari Meksiko dapat meningkatkan pertumbuhan tanaman (tinggi tanaman, jumlah daun, dan luas daun), biomassa tanaman, dan property dari kimia tanah $\left(\mathrm{pH}\left(\mathrm{H}_{2} \mathrm{O}\right)\right.$, karbon organik dan total

Cite this as: Sparta, A., Rahmi, A., Santoso, P J, \& Fitrianingsih, I. (2021). The potency of mexican sunflower extract as the replacement of manure and rice husk charcoal in banana seedling. Jurnal Agro, 8(1), 40-54. https://doi.org/10.15575/11021 
nitrogen). Aplikasi dari ekstrak bunga matahari Meksiko dua kali seminggu ke media tanah menghasilkan tinggi tanaman, jumlah daun, luas daun dan total biomassa tanaman yang lebih baik dibandingkan perlakuan lainnya. Hasil ini menunjukkan bahwa ekstrak bunga matahari Meksiko dapat menggantikan peran dari pupuk kandang sapi dan sekam bakar sebagai sumber nutrisi bagi bibit pisang.

Kata kunci : media tumbuh, bunga matahari Meksiko, pertumbuhan, pisang

\section{INTRODUCTION}

The growth and development of plants are determined by two main factors. The first factor is the genetic (genotype) (NunesNesi et al., 2016; Pohl et al., 2019), which describes plant characters that are inherited from its parents. The second is an environmental factor (carbon dioxide, water, radiation, temperature, and nutrient) (Amoo \& Babalola, 2017; He et al., 2019; Zhu et al., 2018). To grow normally or even reached optimal production, the plant will combine its genotype superiority with several environmental factors (Choi \& Oh, 2016; Meijer \& Leuchtmann, 2000). Suboptimal growth of plants could be occured due to less support from its environmental factors (Abass et al., 2016).

Nutrient either macronutrient or micronutrient, is one of the important factors that could limit plant growth and development, even the potential yield (Guo et al., 2019; Petropoulos et al., 2018; Swift et al., 2020). In nursery conditions, media composition (with its combination nutrient) plays an important role in the growth and development of plant seedlings (Mony et al., 2019). The suitable media composition combine with cultivation technique are able to support better plant growth and development during nursery condition ( Kim et al., 2018; Aung et al., 2019; Lee et al., 2019; Salisu, Sulaiman, \& Samad, 2020). The suitable media composition also provide sufficient nutrient and prepare good soil aeration and drainage (Obia et al., 2018).

According the data form BPS-Statistic Indonesia (2019), banana is known as the first important fruit crop in Indonesia(BPSStatistic Indonesia, 2019); is cultivated in many provinces in Indonesia. The banana production keeps increasing every year and is followed by an increase in seedling demand. In 2018, banana production in Indonesia is about 101.7 tons; this number showed an increase in production of around $1.42 \%$ compared to banana production in 2017 (BPS-Statistic Indonesia, 2019). This fruit crop is propagated by conventional propagation (using banana corm) and micropropagation methods (in vitro propagation) (Sparta \& Emilda, 2020). Before planting into the fields, banana seedlings need to be maintained in the nursery for several months.

Additional organic manure into planting medium is the common practice in the nursery. The organic manure serves several important nutrients during seedling growth, i.e nitrogen, phosphorus, potassium, calcium, magnesium (Aisueni et al., 2009; Han et al., 2016). The application of organic manure also improves soil fertility, soil $\mathrm{pH}$, and several plant growth parameters (Han et al., 2016). In Azadirachta indica, the application of organic manure from poultry improved plant height, stem diameter, and the number of leaves of seedling (Jibo et al., 2018). Experiment Oroka \& Ureigho (2019) 
also resulted in better growth parameters in African mango seedling.

Several practicals in the nursery also added rice husk charcoal into the planting media. This medium improve soil $\mathrm{pH}$ in an acid condition, increase nutrient availability and soil porosity, supporting root growth, improve physical and chemical properties of soil, and increase plant productivity (Nurhidayati \& Mariati, 2014; Li et al., 2018; Ginandjar et al., 2019; Bernard, Latif, \& Edmond, 2020; Renfiyeni et al., 2020). Experiment Ainiah et al., (2019) showed the superior growth in plant height, diameter, and the number of leaves of Tanjung seedlings in media soil + rice husk charcoal compared to other treatments. Additional rice husk charcoal into the soil and cow manure in planting medium of strawberry also resulted in the longest root of strawberry (Renfiyeni, 2020).

However, in some areas, the availability of organic manure and rice husk charcoal is limited. Additional those two media for media combination of seedlings are costly to the farmer. The farmer needs to invest more capital in order to prepare organic manure and rice husk charcoal as the media composition during the seedling condition. The manure and rice husk charcoal processing also resulted in increasing several greenhouse gasses emission that contributed to a negative impact on human health and climate (Mohammadi et al., 2017; Sanchis et al., 2014; Sejian et al., 2016; Wattiaux et al., 2019). Therefore, in order to replace those two potential planting mediums, we need to find a medium that easy to access, less cost, and sustainable for the environment.

Extract Mexican sunflower (Tithonia diversifolia) could be one of the suitable choices as the replacement for organic manure and rice husk charcoal. This kind of plant is found growing in several areas in Indonesia as the abandoned plant. Due to the limited knowledge, many farmers could not get the benefit from this multifunctional plant. Mexican sunflower contains several beneficial nutrients to support plant growth and development (nitrogen, phosphorus, potassium, calcium, and magnesium), improve soil microbial biomass, and limit phosphorus sorption (Jama et al., 2000; Olabode et al., 2007).

Several experiments showed a positive result when Mexican sunflower (compost or liquid extract) was introduced for agricultural purposes. Application 0.5 ton per hectare of Mexican sunflower leaves in garlic was beneficial for soil fertility, plant growth, yield, and in turn improve farmer income (Pierre et al., 2019). In the soilless media, medium with biomass of this plant promoted better growth performance of amaranth compared with natural soil condition (Chemutai et al., 2019). Experiment Taiwo \& Makinde (2005) showed a positive result in cowpea growth by application extract Mexican sunflower. This extract also provided several nutrients for fluted pumpkins and reduced insect pest incidents (Oyerinde et al., 2009).

However, limited information is found regarding the application of extract Mexican sunflower as the replacement function of organic manure and rice husk charcoal in the banana seedling. The purpose of this study is to examine the ability of Mexican sunflower extract to replace the function of organic manure and rice husk charcoal as the source of nutrients for banana plants in seedling conditions. 


\section{MATERIALS AND METHOD}

\section{Experimental site}

This experiment was conducted in Aripan Experimental Station, Indonesian Tropical Fruit Research Institute from July 2019 until April 2020. Aripan Experimental Station is located at $0^{\circ} 44^{\prime} 17^{\prime \prime} \mathrm{S}$ and $100^{\circ} 37^{\prime} 20^{\prime \prime} \mathrm{E}$ with an altitude $425 \mathrm{~m}$ above sea level.

\section{Experimental Design}

This experiment was arranged in a Completely Randomized Design with seven treatments and three replications. The treatments were: 1 ) soil medium with onetime application of Mexican sunflower extract per week (S1T), 2) soil medium with two times application of Mexican sunflower extract per week (S2T), 3) soil medium with three times application of Mexican sunflower extract per week (S3T), 4) soil medium and rice husk charcoal $(1: 1 ; \mathrm{v} / \mathrm{v})$ with one-time application of Mexican sunflower extract per week (SR1T), 5) soil medium and rice husk charcoal $(1: 1 ; \mathrm{v} / \mathrm{v})$ with two times application of Mexican sunflower extract per week (SR2T), 6) soil medium and rice husk charcoal $(1: 1 ; \mathrm{v} / \mathrm{v})$ with three times application of Mexican sunflower extract per week (SR3T), and 7) soil medium, rice husk charcoal, and organic manure (1:1:1; v/v/v) (SRC) as a control. In this experiment we used organic manure from cow, as the common practice in this area. In every treatment application, except treatment SRC, the extract of Mexican sunflower was applied $2 \mathrm{ml}$ per pot.

\section{Preparation of liquid fertilizer of Mexican sunflower}

Fourty $\mathrm{cm}$ from the shoot tip of Mexican sunflower biomass were cutted and collected from the field as the source to get the extract of Mexican sunflower. This biomass was put in the bag and was hanged dry air for two weeks to separate between the solid biomass and liquid extract. After that, nine litter of Mexican sunflower liquid extract were combined with 1 liter of coconut water and $1 \mathrm{~kg}$ brown sugar. For the activator during the anaerobe fermentation process, $250 \mathrm{ml}$ ROTAn (Ramuan Organik Tanaman) was added into a medium combination. And then, all the combination formulas were fermented in an anaerobe process for 30 days. After that, the liquid fertilizers were ready to apply.

Table 1. Soil chemical analysis of three media compositions at the beginning of the experiment

\begin{tabular}{|c|c|c|c|}
\hline Media & Parameter & Value & $\begin{array}{l}\text { Criteria (Eviati } \\
\text { and Sulaiman, } \\
\text { 2015) }\end{array}$ \\
\hline \multirow[t]{3}{*}{ Soil } & $\mathrm{pH}\left(\mathrm{H}_{2} \mathrm{O}\right)$ & 4.1 & Very acid \\
\hline & Organic carbon (\%) & 1.8 & Low \\
\hline & Total nitrogen & 0.07 & Low \\
\hline \multirow[t]{3}{*}{ Soil + Rice husk charcoal } & $\mathrm{pH}\left(\mathrm{H}_{2} \mathrm{O}\right)$ & 6.2 & Slightly acid \\
\hline & Organic carbon (\%) & 5.1 & Very high \\
\hline & Total nitrogen & 0.13 & Low \\
\hline \multirow[t]{3}{*}{ Soil + Rice husk charcoal + Cow manure } & $\mathrm{pH}\left(\mathrm{H}_{2} \mathrm{O}\right)$ & 6.3 & Slightly acid \\
\hline & Organic carbon (\%) & 7.6 & Very high \\
\hline & Total nitrogen & 0.19 & Low \\
\hline
\end{tabular}


The formula showed the chemical analysis as follows: $\mathrm{pH}\left(\mathrm{H}_{2} \mathrm{O}\right) 7.5$, organic carbon $0.7 \%$, total N $0.2 \%$, total P $0.009 \%$, and total $\mathrm{K} 0.6 \%$.

\section{Preparation of planting material}

The planting material was banana seedlings cv. Barangan from tissue culture propagation. These seedlings were prepared around seven months before the experiment. The explants were initiate in Murashige and Skoog (MS) medium (Murashige \& Skoog, 1962) + 4 ppm Benzyl Amino Purine (BAP) +2 ppm Indole Acetic Acid (IAA) and then subculture in MS medium +5 ppm BAP +2 ppm IAA for several times. Plantlets were removed from the bottle, cleansed the agar media, separated into individual plantlets, and washed in clean water. After that, the plantlets were removed into acclimatization media and covered by transparent plastic for one month. After the acclimatization process, the plantlets were removed and planted into the treatment media.

Plant growth media of banana were prepared three days before planting. There were three type of media based on the treatment. The first medium was soil for treatments S1T, S2T, and S3T. The second medium were combination soil and rice husk charcoal $(1: 1 ; \mathrm{v} / \mathrm{v})$ for treatments SR1T, SR2T, and SR3T. While the last medium were combination soil, rice husk charcoal, and organic manure $(1: 1: 1 ; \mathrm{v} / \mathrm{v} / \mathrm{v})$ as the control.

\section{Data Collection}

Soil chemical properties were analyzed at the beginning and at the end of the experiment. While the seedling growth parameters such as plant height, number of leaves, leaf area were observed every two weeks until the end of the experiment. The data of destructive analysis for a dry weight of leaves and roots also collected at the end of the experiment.

\section{Statistical Analysis}

The data of plant height, number of leaves, leaf area, roots length, dry weight of leaves, dry weight of roots, and total dry weights were analyzed using software SPSS 17 software package. Analysis of variance (ANOVA) was used to test the experimental treatment effects. If there were significant effect between treatments, the test was followed by Duncan New Multiple Range Test (DNMRT) at $p<0.05$.

\section{RESULTS AND DISCUSSION}

\section{Soil Analysis}

The availabilities of nutrients, water, and temperature could limit the growth and development of plants, including in the seedling stage ( Villagra \& Cavagnaro, 2006; Gu et al., 2018; Gillis et al., 2019). Planting media not only prepare as a place for a plant to grow but also provide nutrient in order to support seedling growth (Mony et al., 2019). In this experiment, we try to analyze plant growth based on different nutrient input into planting media.

The different nutrient inputs in this experiment came from different media combinations with an additional of Mexican sunflower extract. Seven combinations of seedling media were tested in this experiment. A combination media with soil, rice husk charcoal, and manure was used as a control.

At the beginning of the experiment, soil chemical analysis was measured for each different combination media. Treatments with only use soil medium as the banana seedling growing media (treatments S1T, $\mathrm{S} 2 \mathrm{~T}$, and S3T) showed a low $\mathrm{pH}$, low organic 
carbon, and low nitrogen compared to other media combinations (Table 1). This experiment used ultisol type soil as the soil medium for all treatments. The complexity of medium combination was linear with the increase of $\mathrm{pH}$, organic carbon, and total nitrogen. Treatment SRC; the most complex medium combination (soil + rice husk charcoal + cow manure); resulted in the highest $\mathrm{pH}$, organic carbon, and total nitrogen compared to other media combinations at the beginning experiment (Table 1). Experiment Moral et al. (2005) showed that animal manure contain high organic carbon and nitrogen. While experiment Mishra et al. (2017) showed that rice husk charcoal contain high organic carbon and improved rice productivity when rice husk charcoal incorporated into soil. Furthermore, additional rice husk charcoal and manure into soil could improve soil chemical of medium.

Table 2. Soil chemical analysis of seven treatments at the end of the experiment

\begin{tabular}{llll}
\hline Treatment & $\mathrm{pH}(\mathrm{H} 2 \mathrm{O})$ & Organic carbon $(\%)$ & Total nitrogen (\%) \\
\hline S1T & 6.41 & 5.49 & 0.15 \\
S2T & 6.31 & 5.69 & 0.12 \\
S3T & 5.85 & 4.67 & 0.15 \\
SR1T & 7.41 & 14.72 & 0.30 \\
SR2T & 6.50 & 6.06 & 0.18 \\
SR3T & 7.19 & 11.24 & 0.27 \\
SRC (control) & 6.71 & 10.54 & 0.27 \\
\hline
\end{tabular}

Note: ${ }^{*}$ S1T = soil medium with one-time application of Mexican sunflower extract per week; S2T = soil medium with two times application of Mexican sunflower extract per week; S3T = soil medium with three times application of Mexican sunflower extract per week; SR1T = soil medium and rice husk charcoal $(1: 1 ; \mathrm{v} / \mathrm{v})$ with one-time application of Mexican sunflower extract per week; SR2T = soil medium and rice husk charcoal $(1: 1 ; \mathrm{v} / \mathrm{v})$ with two times application of Mexican sunflower extract per week; SR3T = soil medium and rice husk charcoal $(1: 1 ; \mathrm{v} / \mathrm{v})$ with three times application of Mexican sunflower extract per week; and SRC = soil medium, rice husk charcoal, and cow manure

At the end of the experiment, treatments with application of Mexican sunflower extract showed increasing in $\mathrm{pH}$, organic carbon, and total nitrogen, especially in treatment that only used soil medium as the growth medium since the beginning of the experiment (Table 2). Application of Mexican sunflower extract into soil media continuously improves soil chemical properties; $\mathrm{pH}$ was changing from the acid condition into the neutral condition and organic carbon improved from low value into high value. This finding is also supported by the previous experiment of Agbede et al. (2013); the application of Mexican sunflower improved soil chemical properties in the pot experiment of okra (Abelmoschus esculentus). Experiment Senarathne et al. (2019) also resulted in similar result when Mexican sunflower were introduced in coconut plantation in Srilanka.

\section{Plant Growth Parameter}

During the experiment, several growth parameters were observed periodically, and the other parameters were observed at the end of the experiment. Plant height, number of leaves, and leaf area were observed in 2 , $4,6,8,10$, and 12 WAT. While the dry matter above and below ground was observed in 12 WAT. The result of analysis of variance showed that combination planting media with application Mexican sunflower extract was significant at $p \leq 0.05$ and $p \leq 0.01$ in 
several growth parameters (Figures 1, 2, and 3; Table 2), especially for plant height, number of leaves, leaf area, dry matter of shoot and root, and total dry matter.

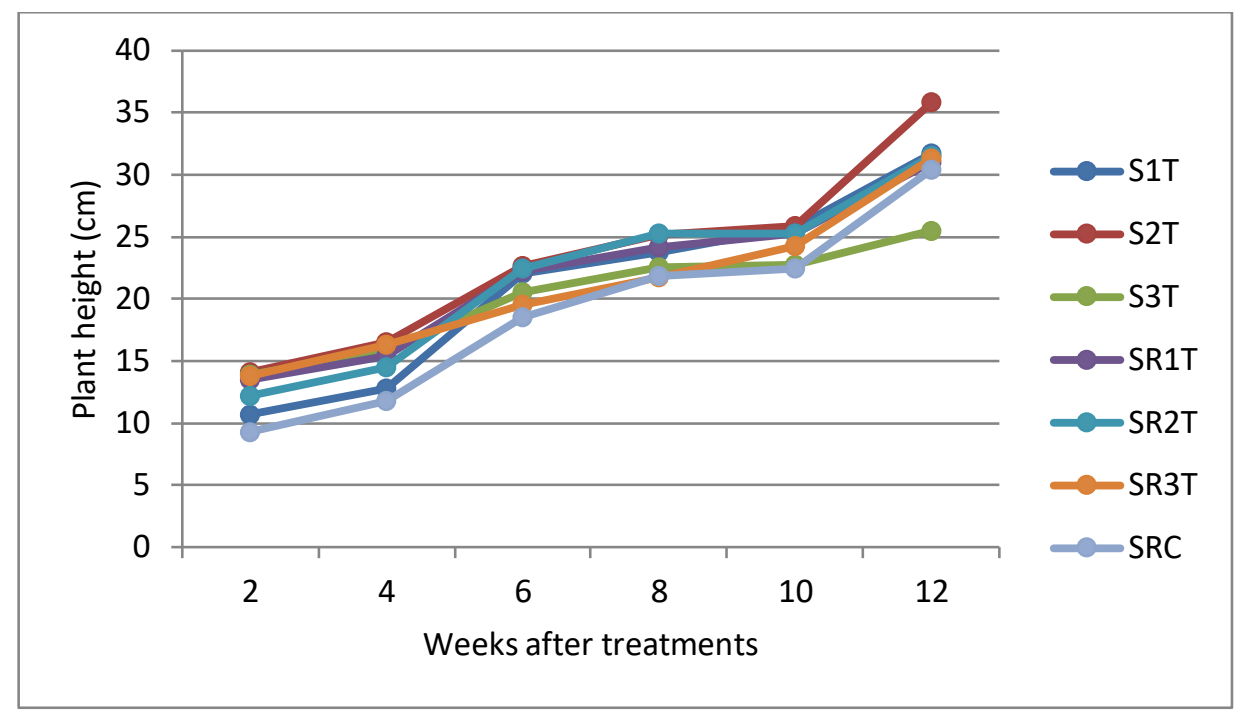

Figure 1. Plant height banana seedlings in seven treatments of media composition. S1T = soil medium with one-time application of Mexican sunflower extract per week; S2T = soil medium with two times application of Mexican sunflower extract per week; S3T = soil medium with three times application of Mexican sunflower extract per week; SR1T = soil medium and rice husk charcoal $(1: 1 ; \mathrm{v} / \mathrm{v})$ with one-time application of Mexican sunflower extract per week; SR2T = soil medium and rice husk charcoal (1:1; v/v) with two times application of Mexican sunflower extract per week; SR3T = soil medium and rice husk charcoal $(1: 1 ; \mathrm{v} / \mathrm{v})$ with three times application of Mexican sunflower extract per week; and SRC = soil medium, rice husk charcoal, and cow manure

Plant height of banana seedlings was significantly affected by extract treatment into different media combinations (Figure 1). Plant height of banana seedlings only showed significant differences in $2,4,(p \leq$ 0.01 ) and 12 WAT ( $\leq 0.05)$. While, in 6,8 , and 10 WAT, the plant height of this seedling was similar. At the end of observation, the tallest banana seedling was found in a soil medium with two times application of liquid fertilizer (S2T). However, this result was not significantly different from the control (SRC).
Sufficient nutrient availability allows seedlings to grow above and below ground. Treatment S2T; soil medium with application two times a week of Mexican sunflower extract; resulted in the tallest seedling compared to other treatments. This treatment provided sufficient nutrients to support shoot growth of banana seedlings. This finding was similar to the result in the experiment of Taiwo \& Makinde, (2005); the highest cowpea was found in the application extract shoot of Mexican sunflower into the soil. 


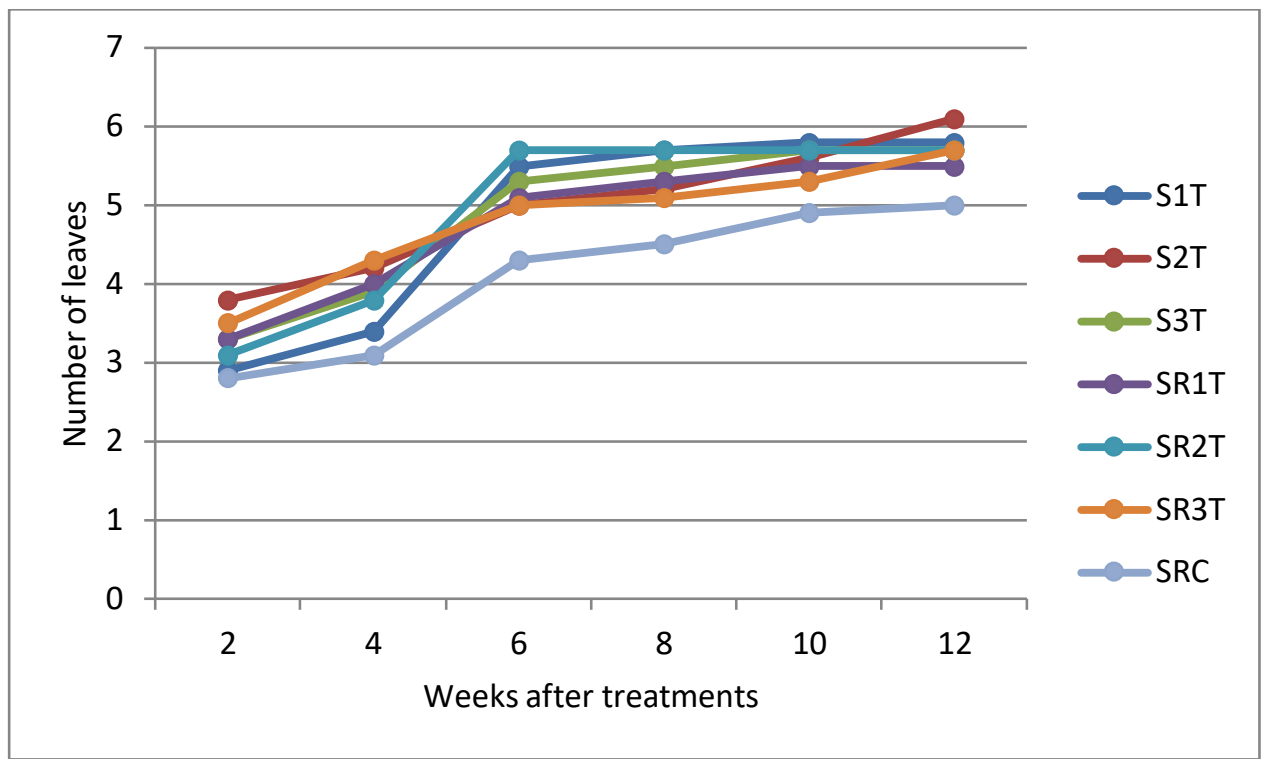

Figure 2. Number of leaves of banana seedlings in seven treatments of media composition. S1T = soil medium with one-time application of Mexican sunflower extract per week; S2T = soil medium with two times application of Mexican sunflower extract per week; S3T = soil medium with three times application of Mexican sunflower extract per week; SR1T = soil medium and rice husk charcoal ( $1: 1 ; \mathrm{v} / \mathrm{v})$ with one-time application of Mexican sunflower extract per week; SR2T $=$ soil medium and rice husk charcoal $(1: 1 ; \mathrm{v} / \mathrm{v})$ with two times application of Mexican sunflower extract per week; SR3T = soil medium and rice husk charcoal $(1: 1 ; v / v)$ with three times application of Mexican sunflower extract per week; and SRC = soil medium, rice husk charcoal, and cow manure

Planting media composition with application of Mexican sunflower extract also affected the number of leaves of banana seedlings (Figure 2). The number of leaves of banana seedlings was significantly different at 2, 4, 6, 8, and 12 WAT. Treatment S2T showed a positive result in the number of leaves of banana seedlings. This treatment resulted in the highest number of leaves at the end of observation times (12 WAT). However, the result for the leaf area parameter in this treatment was almost similar to the control treatment

Analysis of variance also showed significant differences at $p \leq 0.05$ for leaf area of banana seedling due to different treatments (Figure 3). Significant differences were found in $2,6,8,10$, and 12 WAT, while no significant difference was found in 4 WAT. In 12 WAT, the largest leaf area of banana seedling was found in a treatment S2T. This result only significantly differences with treatment S3T.
Several parameters for leaf growth that were observed periodically until the end of the experiment showed that liquid fertilizer of Mexican sunflower could support the shoot growth of banana seedlings. Treatment S2T could promote the same growth of plant leaves of banana seedlings with treatment SRC; the most complex planting medium (soil + rice husk charcoal + manure). Plant leaves have many functions that benefited plant growth and development, especially for the photosynthesis process (Gong et al., 2020). In other words, better growth of plant leaves contributed to better performance of the plant above and below ground.

\section{Plant Biomass}

The shoot and root of seedlings were measured at the end of the experiment (12 WAT). Significant differences were found in the total dry weight and the dry weight of 
shoot. While the dry weight of root of banana seedling showed an almost similar result (Table 3).

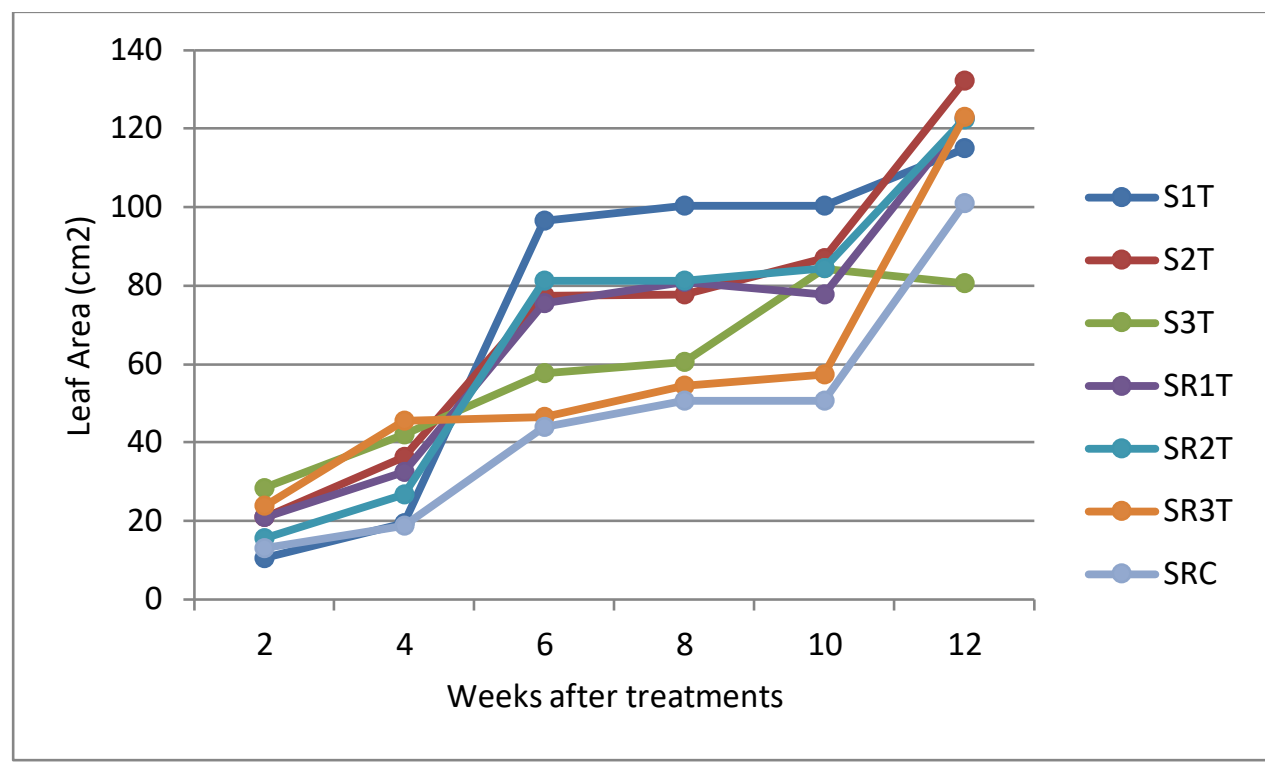

Figure 3. Leaf area of banana seedlings in seven treatments of media composition. S1T = soil medium with one-time application of Mexican sunflower extract per week; S2T = soil medium with two times application of Mexican sunflower extract per week; S3T = soil medium with three times application of Mexican sunflower extract per week; SR1T = soil medium and rice husk charcoal $(1: 1 ; \mathrm{v} / \mathrm{v})$ with one-time application of Mexican sunflower extract per week; SR2T = soil medium and rice husk charcoal $(1: 1 ; \mathrm{v} / \mathrm{v})$ with two times application of Mexican sunflower extract per week; SR3T = soil medium and rice husk charcoal $(1: 1 ; \mathrm{v} / \mathrm{v})$ with three times application of Mexican sunflower extract per week; and SRC = soil medium, rice husk charcoal, and cow manure

In line with the result in other plant parameters, treatment S2T showed superiority in the total dry weight and shoot dry weight of banana seedlings compared to other treatments. Even, this treatment produces two times heavier dry weight (total and shoot) than control treatment. Experiment Setyowati et al. (2018) also reported high total biomass of plant when compost Mexican sunflower were introduced into cauliflower plant. The increasing of compost application was followed by additional weight of plant biomass. This result could be happened due to the increasing of macro and micro nutrient (Hutabarat et al., 2019) in suitable media composition that allow plant to growth better than the other treatments.

Mexican sunflower acts several roles in plant growth and development. In some plant species, this herbaceous plant could act as a bio stimulator that can promote better growth. Application Mexican sunflower promote better growth in common bean (Mkindi et al., 2020), plantain banana (Ewané et al., 2020; Tatsegouock et al., 2020), cowpea (Taiwo \& Makinde, 2005), tomato (Aghofack-Nguemezi et al., 2016; Salami et al., 2017) and rice (Imani et al., 2020). Application Mexican sunflower also beneficial for soil chemichal and physical properties (Dayo-Olagbende et al., 2019). However, the Mexican sunflower also could 
inhibit the growth and development of several plant species, especially the younger plant; less than two weeks old (Oyerinde et al., 2009).

Table 3. Dry weight of leaf, dry weight of root, and total dry weight of banana seedlings in seven treatments of media composition

\begin{tabular}{lllll}
\hline No & Treatment & Dry weight of leaf & Dry weight of root & Total dry weight \\
\hline 1 & S1T* & $0.82 \mathrm{bc}^{* * *}$ & $0.16^{\mathrm{ns}^{* * * *}}$ & $0.98 \mathrm{bc}^{* *}$ \\
2 & S2T & $1.00 \mathrm{c}$ & 0.17 & $1.17 \mathrm{c}$ \\
3 & S3T & $0.39 \mathrm{a}$ & 0.08 & $0.47 \mathrm{a}$ \\
4 & SR1T & $0.43 \mathrm{a}$ & 0.10 & $0.53 \mathrm{a}$ \\
5 & SR2T & $0.65 \mathrm{abc}$ & 0.09 & $0.74 \mathrm{abc}$ \\
6 & SR3T & $0.72 \mathrm{abc}$ & 0.20 & $0.92 \mathrm{abc}$ \\
7 & SRC & $0.50 \mathrm{ab}$ & 0.09 & $0.59 \mathrm{ab}$ \\
\hline
\end{tabular}

Note: ${ }^{*} \mathrm{~S} 1 \mathrm{~T}=$ soil medium with one-time application of Mexican sunflower extract per week; S2T = soil medium with two times application of Mexican sunflower extract per week; S3T = soil medium with three times application of Mexican sunflower extract per week; SR1T = soil medium and rice husk charcoal $(1: 1 ; \mathrm{v} / \mathrm{v})$ with one-time application of Mexican sunflower extract per week; SR2T = soil medium and rice husk charcoal $(1: 1 ; \mathrm{v} / \mathrm{v})$ with two times application of Mexican sunflower extract per week; SR3T = soil medium and rice husk charcoal $(1: 1 ; \mathrm{v} / \mathrm{v})$ with three times application of Mexican sunflower extract per week; and SRC = soil medium, rice husk charcoal, and cow manure ${ }^{* *}=$ Numbers followed by the different lowercase letters in one column showed significant difference at $5 \%$ of DNMRT test.

$n s^{* * *}=$ no significant difference at $5 \%$ of DNMRT test.

The result of this experiment showed that application liquid fertilizer of Mexican sunflower into soil was beneficial for the growth of banana seedling, even in acid soil condition. This liquid promotes plant growth (plant height, number of leaves, and leaf area), improve plant biomass, and improve soil chemical properties $(\mathrm{pH}$, organic carbon, and total nitrogen). Application twice a week of Mexican sunflower extract could replace the function of manure and rice husk charcoal as the nutrient source in banana seedlings. This treatment resulted in highest plant height, number of leaves, leaf area, and total biomass of plant.

\section{CONCLUSION}

1. Application of Mexican sunflower extract into soil media indeed was beneficial for banana seedling growth.
2. The treatment with two times application of this extract resulted in better plant growth performance compared to more complete media combination.

3. This experiment proved that this fertilizer could replace cow manure and rice husk charcoal function as the source of nutrient in banana seedling.

\section{REFERENCES}

Abass, M., \& Moradtalab, N. (2016). Plant growth under drought stress: Significance of mineral nutrients. https://doi.org/10.1002/97811190544 50.ch37

Agbede, T. M., Adekiya, A. O., \& Ogeh, J. S. (2013). Effects of Chromolaena and Tithonia mulches on soil properties, leaf nutrient composition, growth and yam yield. West African Journal of Applied Ecology, 21(1), 15-29. https://doi.org/10.4314/wajae.v21i1 
Aghofack-Nguemezi, J., Juvet, H., \& Dzukam, C. (2016). Impact Factor: RJIF 5.22 www.biotechjournals.com Volume 1; Issue 5. International Journal of Biology Research. Retrieved from www.biotechjournals.com

Ainiah, S., Bakri, S., Muhammad, D., Effendy, M., \& Kehutanan, J. (2019). Pengaruh komposisi media tanam terhadap pertumbuhan semai tanjung (Mimusops elengi L.) Jurnal Sylva Scienteae (Vol. https://doi.org/10.20257/10.20527/JS S.V6I3

Aisueni, N. O., Ikuenobe, C. E., Okolo, E. C., \& Ekhator, F. (2009). Response of date palm (Phoenix dactylifera) seedlings to organic manure, $N$ and $K$ fertilizers in polybag nursery. African Journal of Agricultural Research (Vol. 4). Academic Journals. https://doi.org/10.5897/AJAR.900059 5

Amoo, A. E., \& Babalola, O. O. (2017). Ammonia-oxidizing microorganisms: Key players in the promotion of plant growth. Journal of Soil Science and Plant Nutrition. Sociedad Chilena de la Ciencia del Suelo. https://doi.org/10.4067/S071895162017000400008

Aung, A., Youn, W. Bin, Seo, J. M., Dao, H. T. T., Han, S. H., Cho, M. S., \& Park, B. B. (2019). Effects of three biomaterials mixed with growing media on seedling quality of Prunus sargentii. Forest Science and Technology, 15(1), 13-18. https://doi.org/10.1080/21580103.20 18.1557564

Bernard, N. B., Latif, I. N., \& Edmond, G. T. (2020). Biochar as an alternative growth medium for tree seedlings in the Guinea Savanna Zone of Ghana. African Journal of Plant Science, 14(7), 248-253.

https://doi.org/10.5897/ajps2019.179 6

BPS-Statistic Indonesia. (2019). Statistik Tanaman Buah-buahan dan Sayuran
Tahunan Indonesia. Retrieved January 21, 2021, from https://www.bps.go.id/publication/20 19/10/07/1846605363955649c9f6dd6 d/statistik-tanaman-buah-buahandan-sayuran-tahunan-indonesia2018.html

Chemutai, R., Mwine, J., Awichi, R., \& Bwogi, G. (2019). African Journal of Agricultural Research Effects of NPK and plant tea manure (Tithonia diversifolia) on growth rate of amaranth (Amaranthus cruentus L.) in soilless growing media. African Journal of Agricultural Research, 14(27), 11691179.

https://doi.org/10.5897/AJAR2019.13 928

Choi, H., \& Oh, E. (2016, August 1). PIF4 integrates multiple environmental and hormonal signals for plant growth regulation in Arabidopsis. Molecules and Cells. Korean Society for Molecular and Cellular Biology. https://doi.org/10.14348/molcells.201 6.0126

Dayo-Olagbende, Ewulo, ;, \& Akingbola, B. S. (2019). Combined Effects of Tithonia Mulch and Urea Fertilizer on Soil Physico-Chemical Properties and Maize Performance. Journal of Sustainable Technology, 10(1), 86-93. Retrieved from www.jost.futa.edu.ng

Eviati \& Sulaiman. (2015). Analisis Kimia Tanah, Tanaman, Air, dan Pupuk (Edisi kedu). Bogor: Balai Penelitian Tanah.

Ewané, C. A., Mbanya, N. T., \& Boudjeko, T. (2020). Tithonia diversifolia Leaves and Stems Use as Substrate Amendment Promote the Growth of Plantain Vivoplants in the Nursery. Agricultural Sciences, 11(09), 849-859. https://doi.org/10.4236/as.2020.1190 54

Gillis, L. G., Hortua, D. A. S., Zimmer, M., Jennerjahn, T. C., \& Herbeck, L. S. (2019). Interactive effects of temperature and nutrients on mangrove seedling growth and 
implications for establishment. Marine Environmental Research, 151, 104750. https://doi.org/10.1016/j.marenvres.2 019.104750

Ginandjar, S., Frasetya, B., Nugraha, W., \& Subandi, M. (n.d.). IOP Conference Series: Earth and Environmental Science The Effect of Liquid Organic Fertilizer of Vegetable Waste and Planting Media on Growth and Yield of Strawberry (Fragaria spp.) Earlibrite Cultivar The Effect of Liquid Organic Fertilizer of Vegetable Waste and Planting Media on Growth and Yield of Strawberry (Fragaria spp.) Earlibrite Cultivar. https://doi.org/10.1088/17551315/334/1/012033

Gong, W.-C., Liu, Y.-H., Wang, C.-M., Chen, Y.-Q., Martin, K., \& Meng, L.-Z. (2020). Why Are There so Many Plant Species That Transiently Flush Young Leaves Red in the Tropics? Frontiers in Plant Science, 11 , 83. https://doi.org/10.3389/fpls.2020.000 83

Gu, R., Zhou, Y., Song, X., Xu, S., Zhang, X., Lin, H., ... Zhu, S. (2018). Effects of temperature and salinity on Ruppia sinensis seed germination, seedling establishment, and seedling growth. Marine Pollution Bulletin, 134, 177185.

https://doi.org/10.1016/j.marpolbul.2 017.08.013

Guo, J., Yang, S., Gao, L., Lu, Z., Guo, J., Sun, Y., ... Guo, S. (2019). Nitrogen nutrient index and leaf function affect rice yield and nitrogen efficiency. Plant and Soil, 445(1-2), 7-21. https://doi.org/10.1007/s11104-01904076-z

Han, S. H., An, J. Y., Hwang, J., Kim, S. Bin, \& Park, B. B. (2016). The effects of organic manure and chemical fertilizer on the growth and nutrient concentrations of yellow poplar ( Liriodendron tulipifera Lin.) in a nursery system. Forest Science and Technology, 12(3), 137-143. https://doi.org/10.1080/21580103.20 15.1135827

He, W., Yoo, G., Moonis, M., Kim, Y., \& Chen, $X$. (2019). Impact assessment of high soil CO 2 on plant growth and soil environment: A greenhouse study. PeerJ, 2019(1), e6311. https://doi.org/10.7717/peerj.6311

Hutabarat, R. S., Turmudi, E., \& Setyowati, N. (2019). Effect of Tithonia Compost (Tithonia diversifolia) and Phosphorus On The Growth and Yield of Peanuts. Akta Agrosia, 22(2), 70-76. https://doi.org/10.31186/aa.22.2.7076

Imani Wa Rusaati, B., Kang, J.-W., Gendusa, P. A., Bisimwa, P. B., Kasali, J. L., Rolly, N. K., ... Chirimwami, A. B. (2020). Influence of the application of Tithonia diversifolia and phosphate rocks on the performances of rainfed rice. Korean Journal of Agricultural Science, 47(3), 403-414.

https://doi.org/10.7744/kjoas.202000 29

Jama, B., Palm, C. A., Buresh, R. J., Niang, A., Gachengo, C., Nziguheba, G., \& Amadalo, B. (2000). Tithonia diversifolia as a green manure for soil fertility improvement in western Kenya: A review. Agroforestry Systems, 49(2), 201-221. https://doi.org/10.1023/A:100633902 5728

Kim, H. M., Kim, Y. J., Hwang, S. J., 김혜민, 김영진, \& 황승재. (2018). Physicochemical Properties of Newly Developed Artificial Medium and Proper Irrigation Interval for Production of Tomato Plug Seedlings. Protected Horticulture and Plant Factory, 27(1), 71-79. https://doi.org/10.12791/ksbec.2018. 27.1.71

Lee, H. R., Kim, H. M., Jeong, H. W., Kim, G. G., Na, C. I., Oh, M. M., \& Hwang, S. J. (2019). Growth Characteristics of Adenophora triphylla var. japonica 
Hara Seedlings as Affected by Growing Medium. Plants, 8(11), 466. https://doi.org/10.3390/plants811046 6

Li, Y., Hu, S., Chen, J., Müller, K., Li, Y., Fu, W., ... Wang, H. (2018, February 1). Effects of biochar application in forest ecosystems on soil properties and greenhouse gas emissions: a review. Journal of Soils and Sediments. Springer Verlag. https://doi.org/10.1007/s11368-0171906-y

Meijer, G., \& Leuchtmann, A. (2000). The effects of genetic and environmental factors on disease expression (stroma formation) and plant growth in Brachypodium sylvaticum infected by Epichloë sylvatica. Oikos, 91(3), 446458. https://doi.org/10.1034/j.16000706.2000.910305.x

Mishra, A., Taing, K., Hall, M. W., \& Shinogi, Y. (2017). Effects of Rice Husk and Rice Husk Charcoal on Soil Physicochemical Properties, Rice Growth and Yield. Agricultural Sciences, 08(09), 10141032.

https://doi.org/10.4236/as.2017.8907 4

Mkindi, A. G., Tembo, Y. L. B., Mbega, E. R., Smith, A. K., Farrell, I. W., Ndakidemi, P. A., ... Belmain, S. R. (2020). Extracts of Common Pesticidal Plants Increase Plant Growth and Yield in Common Bean Plants. Plants, 9(2), 149. https://doi.org/10.3390/plants902014 9

Mohammadi, A., Cowie, A. L., Anh Mai, T. L., Brandão, M., Anaya de la Rosa, R., Kristiansen, P., \& Joseph, S. (2017). Climate-change and health effects of using rice husk for biochar-compost: Comparing three pyrolysis systems. Journal of Cleaner Production, 162, 260-272.

https://doi.org/10.1016/j.jclepro.2017 .06 .026

Mony, R., Maliha, M., Akter, D., Islam, R., Rakibuzzaman, M., Maliha, M., ... Jamal
Uddin, A. (2019). Evaluation of growing media for seedling emergence and seedling growth of Red lady papaya. Int. J. Bus. Soc. Sci. Res, 7(4), 27-30. Retrieved from http://www.ijbssr.com/currentissuevi ew/14013333]

Moral, R., Moreno-Caselles, J., Perez-Murcia, M. D., Perez-Espinosa, A., Rufete, B., \& Paredes, C. (2005). Characterisation of the organic matter pool in manures. In Bioresource Technology (Vol. 96, pp. 153-158). Elsevier. https://doi.org/10.1016/j.biortech.200 4.05.003

Murashige, T., plantarum, F. S.-P., \& 1962, undefined. (n.d.). A revised medium for rapid growth and bio assays with tobacco tissue cultures. Files.Florestal81.Webnode.Com.

Retrieved from http://files.florestal81.webnode.com/ 200000040-03153040fe/07 Artigo MS 1962.pdf

Nunes-Nesi, A., Nascimento, V. D. L., De Oliveira Silva, F. M., Zsögön, A., Araújo, W. L., \& Sulpice, R. (2016, May 1). Natural genetic variation for morphological and molecular determinants of plant growth and yield. Journal of Experimental Botany. Oxford University Press. https://doi.org/10.1093/jxb/erw124

Nurhidayati, \& Mariati. (2014). JOURNAL OF DEGRADED AND MINING LANDS MANAGEMENT Utilization of maize cob biochar and rice husk charcoal as soil amendments for improving acid soil fertility and productivity, 2(1), 223230.

https://doi.org/10.15243/jdmlm.2014. 021.223

Obia, A., Mulder, J., Hale, S. E., Nurida, N. L., \& Cornelissen, G. (2018). The potential of biochar in improving drainage, aeration and maize yields in heavy clay soils. PLOS ONE, 13(5), e0196794. https://doi.org/10.1371/journal.pone. 0196794 
Of, E., Manur., \& Jibo. (2018). Salami and Inuha. FJS FUDMA Journal of Sciences (FJS (Vol. 2). Retrieved from www.mwikipedia.org/wiki

Olabode, O., Sola, O., Akanbi, W., G. A.-W. J. of, \& undefined. (n.d.). (2017). Evaluation of Tithonia diversifolia (Hemsl.) A Gray for soil improvement. Citeseer. Retrieved from http://citeseerx.ist.psu.edu/viewdoc/d ownload?doi=10.1.1.415.1021\&rep=re p1\&type=pdf

Oroka, F. O., \& Ureigho, U. N. (2019). Effect of organic manures on the early seedling morphology of Irvingia wombolu Vermoesen in the tropical rainforest of Nigeria. Ceylon Journal of Science, 48(2), 163-168. https://doi.org/10.4038/cjs.v48i2.762 0

Oyerinde, R. O., Otusanya, O. O., \& Akpor, O. B. (2009). Allelopathic effect of Tithonia diversifolia on the germination, growth and chlorophyll contents of maize (Zea mays L.). Scientific Research and Essay, 4(12), 1553-1558. Retrieved from http://www.academicjournals.org/SRE

Petropoulos, S., Fernandes, Â., Karkanis, A., Antoniadis, V., Barros, L., \& Ferreira, I. C. F. R. (2018). Nutrient solution composition and growing season affect yield and chemical composition of Cichorium spinosum plants. Scientia Horticulturae, 231, 97-107. https://doi.org/10.1016/j.scienta.2017 .12 .022

Pierre, W., Chotangui, A. H., Kouankap, D., Tamfuh, P. A., Wotchoko, P., Magha, A., Bello, A. M. (2019). Article no.IJPSS.53715 Reviewers: (1) Sangeeta Shree. Original Research Article Azinwi Tamfuh et Al, IJPSS(4), 118.

https://doi.org/10.9734/ijpss/2019/v3 $1 \mathrm{i} 430219$

Pohl, A., Grabowska, A., Kalisz, A., \& Sękara, A. (2019). The eggplant yield and fruit composition as affected by genetic factor and biostimulant application. Notulae Botanicae Horti Agrobotanici Cluj-Napoca, 47(3), 929-938. https://doi.org/10.15835/nbha473114 68

Renfiyeni, R., Andraini, H., \& Iswaldi, L. (2020). IOP Conference Series: Earth and Environmental Science Growth and yield of Fragaria sp. in mixed and volume of plant media. IOP Conf. Ser.: Earth Environ. Sci, 497, 12007. https://doi.org/10.1088/17551315/497/1/012007

Renfiyeni, R., Andraini, H., Iswaldi, L., \& Renfiyeni, R. (2020). Growth and yield of Fragaria sp. in mixed and volume of plant media. In IOP Conference Series: Earth and Environmental Science (Vol. 497, p. 12007). Institute of Physics Publishing.

https://doi.org/10.1088/17551315/497/1/012007

Salami, A., Coker, O., \& Idowu, O. (2017). Assessment of Soil Fertility Improvement Potential of Water and Methanolic Sunflower (Tithonia diversifolia Hemsl.) Leaf Extract on the Growth and Yield of Tomato (Solanum lycopersicon L.). Journal of Agriculture and Ecology Research International, 13(3), 1-10. https://doi.org/10.9734/jaeri/2017/36 934

Salisu, M. A., Sulaiman, Z., \& Samad, M. Y. A. (2020). Growth and biomass yield of rubber seedlings grown on soilless and soil-based media. Bangladesh Journal of Botany, 49(2), 229-236. https://doi.org/10.3329/bjb.v49i2.492 96

Sanchis, E., Ferrer, M., Calvet, S., Coscollà, C., Yusà, V., \& Cambra-López, M. (2014). Gaseous and particulate emission profiles during controlled rice straw burning. Atmospheric Environment, 98, 25-31.

https://doi.org/10.1016/j.atmosenv.2 014.07 .062

Sejian, V., Bhatta, R., Malik, P. K., 
Madiajagan, B., Al-Hosni, Y. A. S., Sullivan, M., \& Gaughan, J. B. (2016). Livestock as Sources of Greenhouse Gases and Its Significance to Climate Change. In Greenhouse Gases. InTech. https://doi.org/10.5772/62135

Senarathne, S. H. S., Atapattu, A. J., Raveendra, T., Mensah, S., \& Dassanayake, K. B. (2019). Biomass allocation and growth performance of Tithonia diversifolia (Hemsl.) A. Gray in coconut plantations in Sri Lanka. Agroforestry Systems, 93(5), 18651875. https://doi.org/10.1007/s10457018-0290-y

Setyowati, N., Sudjatmiko, S., ... Z. M.-... J. of A., \& 2018, undefined. (n.d.). Growth and yield responses of cauliflower on tithonia (Tithonia diversifolia) compost under organic farming practices. ljatAatsea.Com. Retrieved from http://www.ijat-

aatsea.com/pdf/v14_n7_2018_ December/82_IJAT_14(7)_2018_Setyo wati, N..pdf

Sparta, A. ;, \& Emilda, D. (2020). Growth Evaluation of Banana cv. Barangan as the Effect of Trichoderma sp. and Covering Types during Acclimatization Process. Caraka Tani: Journal of Sustainable Agriculture, 35(2), 268277.

https://doi.org/10.20961/carakatani.v 35i2.41191

Swift, J., Alvarez, J. M., Araus, V., Gutiérrez, R. A., \& Coruzzi, G. M. (2020). Nutrient dose-responsive transcriptome changes driven by Michaelis-Menten kinetics underlie plant growth rates. Proceedings of the National Academy of Sciences of the United States of America, 117(23), 12531-12540. https://doi.org/10.1073/pnas.1918619
117

Taiwo, L. B., \& Makinde, J. O. (2005). Influence of water extract of Mexican sunflower (Tithonia diversifolia) on growth of cowpea (Vigna unguiculata). African Journal of Biotechnology, 4(4), 355-360. Retrieved from http://www.academicjournals.org/AJB

Tatsegouock, R. N., Ewané, C. A., Meshuneke, A., \& Boudjeko, T. (2020). Plantain Bananas PIF Seedlings Treatment with Liquid Extracts of \&lt;i\&gt;Tithonia diversifolia\&lt;/i\&gt; Induces Resistance to Black Sigatoka Disease. American Journal of Plant Sciences, 11(05), 653-671. https://doi.org/10.4236/ajps.2020.115 049

Villagra, P. E., \& Cavagnaro, J. B. (2006). Water stress effects on the seedling growth of Prosopis argentina and Prosopis alpataco. Journal of Arid Environments, 64(3), 390-400. https://doi.org/10.1016/j.jaridenv.200 5.06.008

Wattiaux, M. A., Uddin, M. E., Letelier, P., Jackson, R. D., \& Larson, R. A. (2019, April 1). INVITED REVIEW: Emission and mitigation of greenhouse gases from dairy farms: The cow, the manure, and the field. Applied Animal Science. Elsevier Inc. https://doi.org/10.15232/aas.201801803

Zhu, Z., Ge, T., Liu, S., Hu, Y., Ye, R., Xiao, M., ... Wu, J. (2018). Rice rhizodeposits affect organic matter priming in paddy soil: The role of $\mathrm{N}$ fertilization and plant growth for enzyme activities, $\mathrm{CO} 2$ and $\mathrm{CH} 4$ emissions. Soil Biology and Biochemistry, 116, 369-377. https://doi.org/10.1016/j.soilbio.2017. 11.001 